\title{
SUSTAINABILITY STRATEGY ANALYSIS FOR CLAY INDUSTRY IN GODEAN DISTRICT
}

\author{
Annisa Rahma Fajrin*1 \\ Sri Rahayu Budiani² \\ ${ }^{1,2}$ Fakultas Geografi Universitas Gadjah Mada, Yogyakarta, Indonesia
}

\section{ABSRACT}

The clay industry in Godean Distric existed due to proximity of its raw material. The clay industry has been established since 1930 and began to stop producing. The strategy is needed to maintain the sustainability of this production activity. The aim of this research is to formulate the sustainable strategy using the SWOT analysis. The SWOT analysis is formulated with internal and external factors that influence the sustainability of this industry. The data is analized with descriptive qualitative technique using IFAS Table, EFAS Table, IE Matrix, and SWOT Matrix. The results show that the internal factors are management, the product reputation, inovation, capital, labour, raw material, and business sucessors. The external factors are market, the existance of Asosiasi Pengrajin Genteng, government policies, suppliers and distributors, and competitors. The right strategy to maintain the sustainability of the clay industry is to avoid losing profit and extend the market. One of right way to do is making the own brand.

Keywords: Industrial Sustainability, IFAS, EFAS, SWOT

\section{ABSTRAK}

Industri tanah liat di Kecamatan Godean muncul karena kedekatannya dengan sumber bahan baku. Industri ini telah berdiri sejak tahun 1930-an dan mulai berhenti berproduksi. Dibutuhan strategi yang tepat untuk mempertahankan keberlanjutan industri ini. Tujuan dari penelitian ini untuk merumuskan strategi keberlanjutan industri menggunakan analisis SWOT. Analisis SWOT dirumuskan dari faktor lingkungan internal dan eksternal yang mempengaruhi keberlanjutan industri. Analisis data menggunakan teknik deskriptif kualitatif dengan tabel IFAS, EFAS, Matriks IE, dan Matriks SWOT. Hasil penelitian menunjukkan faktor lingkungan internal dipengaruhi oleh manajemen, reputasi produk, inovasi, modal, tenaga kerja, bahan baku, dan penerus usaha. Faktor lingkungan eksternal yang mempengaruhi yaitu pasar, keberadaan asosiasi pengrajin, kebijakan pemerintah, pemasok dan distributor, serta kompetitor. Strategi yang tepat untuk mempertahankan keberlanjutannya adalah dengan menghindari kehilangan keuntungan dan memperluas pasar. Langkah yang tepat adalah dengan membuat merek dagang sendiri.

Kata Kunci: Keberlanjutan, Industri, IFAS, EFAS, SWOT
RIWAYAT ARTIKEL

Tanggal Masuk: 2 April 2018

Tanggal Direvisi: 12 Mei 2018 Tanggal Diterima: 19 Juni 2018 Tersedia Online: 25 Juni 2018

${ }^{*}$ Korespondensi: Annisa Rahma Fajrin

E-mail: annisaarf@gmail.com

JEL: Z31; L32

JIET (Jurnal Ilmu Ekonomi Terapan) p-ISSN: 2541-1470; e-ISSN: 2528-1879 DOI: $10.20473 /$ jiet.v5i1.19631 


\section{Pendahuluan}

Industri merupakan salah satu sektor ekonomi yang menyumbang kontribusi besar bagi perekonomian Indonesia. Terbukti berdasarkan data (BPS 2017a), dalam rentang waktu dari 2012-2016 kontribusi sektor industri terhadap Produk Domestik Bruto (PDB) adalah sebesar 22,46\%-26,69\% dari total kontribusi keseluruhan sektor perekonomian lainnya. Industri menjadi salah satu dari sektor ekonomi yang menyumbang PDB terbesar di Indonesia. Salah satu bagian dari sektor industri yang dapat bertahan dari krisis moneter Indonesia pada tahun 1998 adalah UMKM (Usaha Mikro, Kecil, dan Menengah) (LPPI \& Bank Indonesia 2015). UMKM juga berfungsi menjadi input dari industri yang lebih besar dan sumber dari inovasi. Pengembangan UMKM di Indonesia juga dinilai dapat menyelesaikan permasalahan daerah seperti mengatasi tingkat pengangguran, memberantas kemiskinan, dan juga meningkatkan pendapatan (BPS 2017b). Lebih lanjut, Porter (1980) dalam Christianto (2011) mengatakan bahwa suatu daerah akan mempertahankan dan mengmbangkan keunggulan kompetitifnya berdasarkan kemampuan inovasi dan keadaan ekonomi yang merupakan hasil dari persaingan industri lokal. Hal ini menujukkan bahwa pengembangan UMKM penting untuk dilakukan dalam menunjang perekonomian masyarakat.

Industri tanah liat di Kecamatan Godean merupakan salah satu UMKM yang berdiri sejak tahun 1930-an dan tetap masih beroperasi hingga sekarang. Aktivitas industri ini mulai ditinggalkan oleh banyak pengrajin/ pengusaha karena dinilai sulit dilanjutkan. Kesulitan ini disebabkan oleh perubahan faktor-faktor produksi yang disebabkan modernisasi. Hal ini sejalan dengan (Tambunan 2012; Prasasti 2016; Aryanti 2017) yang mengatakan bahwa UMKM terancam tidak berproduksi disebabkan oleh kendala faktor modal, pemasaran, inovasi dan pemanfaatan teknologi informasi, bahan baku, peralatan produksi, ketersediaan tenaga kerja, rencana pengembangan usaha, serta kesiapan menghadapi tantangan dari lingkungan eksternal.

Demi mengatasi permasalahan tersebut, dibutuhkan strategi yang tepat untuk menunjang keberlanjutan industri tanah liat di Kecamatan Godean. Strategi dapat disusun dengan mengidentifikasi faktor lingkungan internal dan faktor lingkungan eksternal (Rangkuti 2008). Faktor seperti lingkungan internal dan faktor lingkungan eksternal memiliki peran mengidentifikasi permasalahan yang terdapat di tubuh UMKM. Kedua komponen ini akan dapat memberikan nilai untuk mengarahkan penyusunan strategi yang dirumuskan dalam analisis SWOT.

Berdasarkan uraian di atas, penelitian ini bertujuan untuk mengidentifikasi faktor-faktor lingkungan internal dan lingkungan eksternal yang memberikan pengaruh keberlanjutan industri tanah liat di Kecamatan Godean. Selain itu, penelitian ini juga bertujuan untuk merumuskan strategi keberlanjutan industri yang tepat menggunakan matriks SWOT.

Berdasarkan uraian di atas, penelitian ini bertujuan untuk mengidentifikasi faktor-faktor lingkungan internal dan lingkungan eksternal yang memberikan pengaruh keberlanjutan industri tanah liat di Kecamatan Godean. Selain itu, penelitian ini juga bertujuan untuk merumuskan strategi keberlanjutan industri yang tepat menggunakan matriks SWOT.

\section{Telaah Literatur}

Faktor produksi merupakan sesuatu yang digunakan untuk memproses sebuah input menjadi output dalam suatu kegiatan produksi. Berdasarkan pada ulasan dari Samuelson \& Nordhaus (2010), faktor produksi utama yang dapt mempengaruhi fungsi produksi adalah lahan, tenaga kerja, dan modal. Aspek lahan yang dimaksud tidak hanya dapat berupa lo- 
kasi produksi, namun juga ketersediaan bahan baku. Sementara itu, Ebert \& Griffin (2019), mengatakan bahwa terdapat lima faktor produksi, antara lain seperti sumberdaya manusia maupun sumber daya modal, wirausahawan, sumberdaya fisik, dan sumberdaya informasi. Aspek pasar juga dapat berpengaruh terhadap kegiatan produksi, dimana pasar dapat memberi pengaruh pada tingkat permintaan dan penawaran. Permintaan dan penawaran akan dapat berpengaruh terdapat inovasi, jumlah produksi, dan juga modal yang dikeluarkan dalam proses produksi. Faktor produksi yang ada dalam ulasan tersebut menyangkut keberlanjutan dari industri tanah liat di Kecamatan Godean, dimana berdasarkanobservasi industri ini berdiri disebabkan oleh faktor kedekatan bahan baku. Aspek tenaga kerja yang terdapat di industri tanah liat juga berpengaruh pada keberlanjutan industri, karena tenaga kerja didapatkan dari daerah lain dan mulai berkurang kuantitas jumlahnya sehingga berpengaruh juga terhadap produktivitas industri. Selain itu, aspek pasar dan juga kompetitor menjadi sebuah isu yang dapat menyebabkan terbentuknya kelompok organisasi pengrajin. Hal ini juga sejalan dengan teori faktor produksi yang dapat mempengaruhi keberlanjutan industri.

Faktor produksi yang memiliki pengaruh terdapat keberlanjutan industri secara lebih jelas dapat dibagi menjadi faktor lingkungan internal dan eksternal. Faktor lingkungan diantaranya mengidentifikasi permasalahan industri dari dalam dan luar lingkungan industri, di mana semua faktor produksi diobservasi dan dianalisis. Faktor lingkungan juga dapat digunakan untuk menyusun strategi keberlanjutan dengan matriks SWOT (Strength, Weakness, Opportunity, and Threat), yang akan dapat menghasilkan komponen kekuatan dan kelemahan. Sementara itu, lingkungan eksternal akan menghasilkan sebuah komponen peluang dan ancaman.

Faktor lingkungan internal menyangkut bahan baku, manajemen, layanan yang diberikan, aset modal, tenaga kerja, sistem informasi, riset, dan inovasi (Rangkuti 2008; Porter 1992 dalam Hadiati 2008; Setyowati 2015). Sementara itu, menurut Chattopadhayay (2015) dalam penelitian Dharmarani \& Ghina (2016) bahwa faktor lingkungan eksternal yangberpengaruh terhadap keberlanjutan industri adalah konsumen, kompetitor, dan regulasi juga merupakan faktor yang berpengaruh terdapat keberlanjutan dari industri. Faktor lingkungan internal dan eksternal adalah komponen analisis yang dapat digunakan mengidentifikasi permasalahan yang juga terjadi di lingkungan industri. Faktor pada lingkungan eksternal lain yang juga dapat mempengaruhi keberlanjutan pada industri adalah pemasok dan distributor, produk pengganti, sosial dan budaya, dan politik (Porter 1992 dalam Hadiati 2008; Setyowati 2015; Sari \& Budiani 2018). Faktor-faktor lingkungan akan secara langsung mempengaruhi pengambilan keputusan manajerial, proses, dan juga struktur organisasi, di mana lingkungan yang berubah umumnya diiringi dengan adanya peningkatan kualitas untuk market purpose seperti inovasi, layanan, dan kompetitor.

\section{Metode Penelitian}

Metode penelitian yang digunakan adalah analisis deskriptif. Data yang digunakan dalam penelitian ini berupa data sekunder dan data primer. Data sekunder yang digunakan berupa data jumlah pengrajin dari Asosiasi Pengrajin Genteng Sembada Manunggal untuk menentukan sampel.

Data primer dikumpulkan dengan cara wawancara secara mendalam dengan pemangku kepentingan di lingkungan industri untuk menentukan komponen faktor lingkungan yang berpengaruh serta bobotnya terhadap keberlanjutan industri. Informan diminta untuk menentukan bobot dengan nilai persen. Kemudian nilai persen diubah ke dalam bentuk desimal untuk pengolahan data. 
Hasil wawancara mendalam akan disusun Tabel IFAS dan Tabel EFAS. Wawancara terstruktur juga dilakukan untuk dapat menentukan nilai dari faktor lingkungan untuk menyusun strategi keberlanjutan industri dengan Matriks IE dan Matriks SWOT. Instrumen yang digunakan untuk wawancara terstruktur adalah kuesioner dengan 4 skala, yaitu skala 1 (tidak berpengaruh) sampai skala 4 (sangat berpengaruh).

Penentuan jumlah responden untuk wawancara terstruktur dilakukan dengan metode Slovin Sampling dan penentuan titik sampel digunakan teknik Propotional Random Sampling dikarenakan populasi tersebar di tiga desa yang berbeda (Morissan et al., 2012). Rumus dari Slovin Sampling adalah:

$$
n=\frac{N}{1+\left(N \times e^{z}\right)}
$$

Keterangan:

$\mathrm{n}=$ Jumlah Sampel

$\mathrm{N}=$ Populasi

$\mathrm{e}=$ Margin Error (10\%)

Terdapat 358 pengrajin industri tanah liat di Kecamatan Godean yang tersebar di tiga sentra, yaitu Sentra Sidorejo, Sentra Sidoluhur, dan Sentra di Sidoagung sehingga jumlah sampel diperlukan berdasarkan metode ini adalah:

$$
\begin{aligned}
& n=\frac{N}{1+\left(N \times e^{2}\right)} \\
& n=\frac{358}{1+\left(358 \times 0,1^{2}\right)} \\
& n=78,16 \\
& \approx 78 \text { pengerajin }
\end{aligned}
$$

Rumus dari Propotional Random Sampling adalah:

$$
\text { nproporsi }=\frac{N \text { kelas }}{N} \times n \text { sampel }
$$

Keterangan:

$\mathrm{n}$ Proporsi $=$ Jumlah sampel tiap sentra

n Sampel= Sampel dari Slovin Sampling

$\mathrm{N}=$ Populasi

Wawancara terstruktur dilakukan kepada minimal 78 pengrajin yang berperan sebagai pemilik industri. Berdasarkan data sekunder dari Asosiasi Pengrajin Genteng Sembada Manunggal, diketahui bahwa di Kecamatan Godean terdapat tiga sentra industri dengan jumlah pengrajin berbeda di setiap sentranya. Jumlah populasi dan sampel ditampilkan dalam Tabel 1 


\section{Tabel 1: Jumlah Populasi dan Sampel Penelitian}

\begin{tabular}{ccc}
\hline Sentra & Populasi & Sampel \\
\hline Sidoagung & 126 & 27 \\
\hline Sidoluhur & 147 & 32 \\
\hline Sidorejo & 85 & 19 \\
\hline Jumlah & 358 & 78 \\
\hline
\end{tabular}

Hasil

Industri tanah liat berdiri karena lokasi pengambilan bahan baku berada dekat dengan lokasi produksi. Proses produksi untuk membuat produk tanah liat membutuhkan waktu yang relatif lama karena harus melewati beberapa proses yakni proses penggilingan, pencetakan, penjemuran, dan juga pembakaran. Tenaga kerja tidak memerlukan keahlian khusus, kecuali untuk aktivitas membakar produk.

Modal yang diperlukan untuk memulai industri cukup besar. Alat yang dibutuhkan adalah brak sebagai bangunan untuk proses produksi, ancak dan juga pagan sebagai rak untuk meletakkan hasil dari produksi, tobong juga sebagai tempat pembakaran produk, mesin cetak, ember, terpal, pisau, cangkul, penggilingan, dan lain-lain. Bahan yang dibutuhkan adalah tanah liat dan kayu bakar. Total modal untuk memulai industri dapat mencapai nominal lebih dari Rp40.000.000,-. Bahan baku tanah liat diambil dari perbukitan di sekitar Kecamatan Godean- Seyegan, dimana jumlahnya semakin sedikit karena adanya pembangunan dan kualitasnya yang sudah menurun. Bahan baku lain sebagai bahan subtitusi diambil dari wilayah Kecamatan Kalibawang Kabupaten Kulonprogo dan tanah liat dari sawah di sekitar Provinsi DI Yogyakarta. Harga tanah liat disana berkisar antara Rp140.000 - Rp250.000,- per kol, di mana untuk dapat menghasilkan sejumlah10.000 unit produk dibutuhkan bahan sebesar sebanyak $10 \mathrm{kol}$. Umumnya pengusaha menghasilkan 10.000 unit produk dalam sekali produksi. Sementara itu, harga kayu untuk sekali produksi mencapai Rp1.250.000,-. Tenaga kerja sebagian besar berasal dari masyarakat di Kecamatan Wonosari pada Kabupaten Gunungkidul dengan sistem upah yang borongan. Adapun jumlah upah yang dibayarkan tercantum dalam Tabel 2 .

Tabel 2: Jenis Pekerjaan dan Upah Tenaga Kerja

\begin{tabular}{cc}
\hline Pekerjaan & Upah \\
\hline Mencetak & Rp150.000,- per 1.000 bata/genteng \\
\hline Finishing & Rp40.000 - Rp50.000,- per 1.000 bata/genteng \\
\hline Membakar & Rp200.000,- per 5.000 bata/genteng \\
\hline Mengangkut produk ke tobong & Rp50.000,- per 5.000 bata/genteng \\
\hline
\end{tabular}

Keadaan pasar untuk industri tanah liat di daerah Kecamatan Godean tergolong baik. Jangkauan pasar dapat mencapai Pulau Sumatera, Pulau Bali, dan mancanegara pada tahun tertentu. Adapun daerah pemasaran produk dari wilayah Indonesia yaitu Lampung, Jakarta, Bali, Jawa Barat, Jawa Tengah, Jawa Timur, dan juga D.I Yogyakarta sendiri. Permintaan yang tinggi membuat industri tanah liat di Kecamatan Godean tetap dapat berjalan.

\section{Faktor Lingkungan Internal Industri}

Keadaan lingkungan internal industri tanah liat Kecamatan Godean dapat diidentifikasi melalui aspek produksi, manajemen yang berhubungan dengan budaya perusahaan dan kemampuan berwirausaha, serta ada atau tidaknya pengembangan dalm upaya menjalankan 
industri. Analisis pada faktor lingkungan internal menghasilkan aspek kekuatan (strengths) dan juga kelemahan (weakness) yang dapat digunakan untuk menganalisis SWOT yang menentukan serangkaian strategi yang keberlanjutan industri. Faktor lingkungn saling terkait dan mempengaruhi satu sama lain. Adapun faktor lingkungan internal yang dinilai dapat juga mempengaruhi keberlanjutan industri tanah liat di Kecamatan Godean ditampilkan di tabel 3.

Faktor lingkungan internal industri terdiri dari komponen kekuatan dan juga kelemahan. Diketahui bahwa industri tanah liat di Kecamatan Godean secara karakteristiknya, masih dijalankan oleh pengusaha secara langsung. Pengusaha berperan juga sebagai tenaga kerja dan pengawas dalam suatu proses produksi. Pengawasan ini memiliki tujuan untuk mempertahankan kualitas produk yang akan dihasilkan nanti. Pengusaha juga mengawasi dan terlibat langsung dalam proses pemilihan bahan baku dan tambahan, pengolahan, hingga tahap pemasaran.

Bahkan beberapa dari pengusaha juga memberikan garansi untuk produknya. Hal ini juga menandakan bahwa industri tanah liat di Kecamatan Godean mengutamakan kualitas. Perkembangan pasar membuat pengusaha memciptakan pembaruan jenis produk. Pembaruan jenis produk yang dilakukan yaitu membuat jenis-jenis produk tanah liat baru. Mulanya, industri tanah liat di Kecamatan Godean membuat produk genteng gripik saja namun sekarang dapat menghasilkan produk lain seperti batu bata dengan berbagai jenis produk lainnya. Hal ini disebabkan oleh permintaan pasar yang bervariasi dan upaya pengusaha untuk melakukan inovasi untuk mendapatkan keuntungan yang lebih banyak. Selain itu, inovasi juga bertujuan untuk mempertahankan keberlanjutan dari industri (Yunal \& Indriyani, 2013).

Tabel 3: IFAS Faktor Lingkungan Internal

\begin{tabular}{lccc} 
& Bobot & Nilai & Skor \\
\hline $\begin{array}{l}\text { Kekuatan(Strengths) } \\
\begin{array}{l}\text { Managemen masing-masing usaha yang } \\
\text { dilakukan langsung oleh pemilik indutri }\end{array}\end{array}$ & 0,03 & 3 & 0,09 \\
$\begin{array}{l}\text { Terdapat inovasi pembaruan jenis produk } \\
\text { sesuai dengan kedaan pasar }\end{array}$ & 0,05 & 2 & 0,10 \\
$\begin{array}{l}\text { Reputasi Produk Baik } \\
\text { Kelemahan (Weakness) }\end{array}$ & 0,07 & 3 & 0,21 \\
$\begin{array}{l}\text { Modal yang besar untuk memulai usaha } \\
\text { Kesulitan mendapatkan tenaga kerja }\end{array}$ & 0,22 & 2 & 0,44 \\
$\begin{array}{l}\text { Tidak ada penerususaha } \\
\text { Bahan baku langka dan mahal }\end{array}$ & 0,20 & 3 & 0,60 \\
\hline TOTAL & 0,28 & 2 & 0,56 \\
\hline
\end{tabular}

Kualitas yang selalu dipertahankan oleh para pengusaha industri tanah liat di Kecamatan Godean ini juga membuat reputasi produk tanah liat terkenal baik. Berdasarkan beberapa penuturan, kualitas produk yang baik disebabkan oleh bahan baku yang berkualitas. Bahan baku yang berkualitas adalah tanah lempung yang memiliki daya rekat tinggi dan kadar air yang cukup. Selain itu, proses pengolahannya tetap diperhatikan, di mana pengusaha menggunakan tiga kali proses penggilingan untuk mendapatkan campuran yang halus dengan tujuan membuat produk tidak mudah pecah. Selain itu, pada proses pembakaran pun suhu dan kerataan pada pematangan diperhatikan agar produk berkualitas tinggi.

Akan tetapi, permasalahan kualitas juga berhubungan dengan menurunnya kualitas tanah liat yang berada di bukit-bukit sekitar Kecamatan Godean-Seyegan. Kualitas tanah liat 
yang menurun membuat pengusaha atau pengrajin mencampur tanah liat dari bukit dengan tanah liat yang lebih rekat, yaitu tanah liat dari sawah. Selain kualitas, kuantitas tanah liat bukit juga terindikasi habis karena bukit-bukit terancam habis persediaannya. Padahal menurut Weber (1909) dalam Smith (1971) bahan baku merupakan aspek terpenting yang dapat menentukan besaran biaya produksi karena berhubungan dengan transportasi. Apabila bahan baku yang kualitas dan persediaannya dekat, bukan tidak mungkin industri tanah liat di Kecamatan Godean akan mengalami kemunduran fatal. Meskipun demikian, bahan baku dari bukit- bukit di sekitar Kecamatan Godean-Seyegan yaitu dinilai masih cukup persediaannya untuk jangka waktu yang cukup lama, dibandingkan dengan penurunan jumlah industri hal ini masih memenuhi jumlah permintaan.

Permasalahan lain akibat naiknya harga produksi adalah modal yang ikut naik didukung pula oleh efek inflasi. Modal untuk merintis usaha tidak murah karena untuk membangun suatu bangunan industri juga membutuhkan setidaknya puluhan juta. Alat dan bahan yang harus ada sebelum memulai usaha adalah brak yang berfungsi sebagai bangunan industri dengan kisaran harga Rp15.000.000 - Rp20.000.000,-, ancak dan pagan yang berfungsi untuk meletakkan hasil produk sebelum dibakar yang berkisar antara Rp2.000.000 - Rp5.000.000,-, tobong untuk pembakaran dengan harga Rp15.000.000 -Rp20.000.000,-, cangkul, ember, mesin cetak dengan harga Rp1.500.000,-, kayu dengan kisaran harga Rp500.000 - Rp1.250.000,per kol atau sekali produksi, tanah liat Rp140.000-Rp250.000,- per kol di mana pada proses produksinya membutuhkan sekiranya $10 \mathrm{kol}$, dan lahan yang luas. Setidaknya untuk merintis usaha saat ini membutuhkan modal senilai lebih dari Rp40.000.000,-.Modal yang besar ini juga belum termasuk mengupah para pekerja dan biaya transportasi sehingga memulai usaha adalah hal yang sulit dilakukan untuk industri tanah liat. Selain itu, perputaran uang tidak cepat, karena proses produksi sendiri menghabiskan waktu dua minggu sampai sebulan. Padahal perintis usaha merupakan penerus keberlanjutan industri, di mana perintis menandakan bahwa industri ini akan terus berkembang dan berjalan.

Kemudian faktor produksi lainnya yaitu permasalahan tenaga kerja. Tenaga kerja yang bekerja di industri tanah liat merupakan pekerja buruh dengan upah borongan. Upah borongan berarti pekerjaan dibayar sesuai dengan hasil yang dikerjakan. Sementara itu, pekerjaan di industri tanah liat adalah pekerjaan kasar dengan upah kecil. Upah untuk membakar dalam satu hari untuk 5.000 unit berkisar Rp200.000 - Rp250.000,-, upah mengangkut dan merapikan adalah Rp40.000-Rp50.000,- per 5.000 unit, dan upah mencetak adalah Rp150.000,- per 1.000 unit hingga produk kering dijemur. Padahal dalam sekali produksi, sebagian besar industri hanya menghasilkan 5.000 unit dalam waktu yang tidak sebentar. Hal ini mengartikan bahwa upah yang diterima oleh tenaga kerja sangat kecil.

Upah yang sangat kecil membuat tenaga kerja kasar untuk bekerja di industri tanah liat sulit dicari. Sementara itu, beban kerja tidak dapat ditanggung sendiri oleh pengusaha sehingga kegiatan produksi terhambat dan tidak dapat memenuhi permintaan pasar. Hal ini didukung pula oleh Weber (1909) dalam Smith (1971) produktivitas tenaga kerja mempengaruhi biaya produksi, sehingga akan berpengaruh pada jumlah modal dan keuntungan. Masalah lingkungan internal industri tanah liat Kecamatan Godean juga muncul dari tidak adanya penerus usaha. Sebagian besar anak dari pengusaha tidak berorientasi meneruskan usaha orang tuanya. Hal ini disebabkan karena jenis pekerjaan yang kasar, perputaran uang yang lama, dan adanya pergeseran budaya pada masyarakat yang menanggap jika bekerja sebagai pegawai lebih baik daripada menjadi pengusaha. Penerus usaha adalah faktor utama dalam keberlanjutan industri, karena tanpa penerus usaha maka industri tanah liat di Kecamatan Godean tidak dapat bertahan. Hal ini yang seharusnya ditanamkan oleh orang tua bahwa menja- 
di pengusaha merupakan pekerjaan yang sama baiknya dengan menjadi pegawai.

Faktor-faktor dalam lingkungan internal menunjukkan bahwa bobot yang besar justru berada di bagian kelemahan. Kelemahan pada lingkungan internal didominasi oleh masalah faktor produksi, yaitu modal, tenaga kerja, dan bahan baku. Faktor lain yang sangat dominan justru merupakan persoalan penerus usaha, di mana termasuk dalam sumberdaya manusia yang berkemampuan dan berkemauan untukberwirausaha.

\section{Faktor Lingkungan Eksternal Industri}

Faktor lingkungan eksternal industri yang berpengaruh terhadap kebelanjutan industri tanah liat di Kecamatan Godean ditampilkan dalam Tabel 4 yaitu sebagai berikut

Tabel 4: EFAS Faktor Lingkungan Eksternal

\begin{tabular}{|c|c|c|c|}
\hline & Bobot & Nilai & Skor \\
\hline \multicolumn{4}{|l|}{ Peluang (Opportunities) } \\
\hline Pasar dengan permintaan tinggi & 0,30 & 3 & 0,90 \\
\hline Upaya standarisasi dari Asosiai Pengrajin Genteng & 0,20 & 2 & 0,40 \\
\hline Pasar luas & 0,25 & 2 & 0,50 \\
\hline $\begin{array}{l}\text { Peran pemerintah memberikan rekomendasi bahan bangunan untuk } \\
\text { pembangunan dari industri tanah liat godean }\end{array}$ & 0,13 & 1 & 0,26 \\
\hline Memiliki banyak mitra dengan pemasok dan distributor & 0,04 & 3 & 0,12 \\
\hline \multicolumn{4}{|l|}{ Ancaman(Threats) } \\
\hline Pesaing memalsukan merek dan masuk ke daerah Godean & 0,08 & 3 & 0,24 \\
\hline TOTAL & 1 & & 2,42 \\
\hline
\end{tabular}

Faktor seperti lingkungan eksternal dapat diidentifikasi pertama ditinjau dari keadaan pasar. Pasar merupakan salah satu faktor produksi yang memiliki pengaruh permintaan dan penawaran yang akan menentukan berlanjutnya suatu industri (Smith, 1971). Keadaan pasar industri tanah liat di Kecamatan Godean tergolong baik, di mana permintaan selalu tinggi. Permintaan yang tinggi ini membuat pengusaha atau pengrajin memproduksi produknya dapat secara rutin. Permintaan yang tinggi juga membuat industri tanah liat di Kecamatan Godean tetap berlanjut hingga sekarang. Permintaan yang tinggi tidak terlepas dari reputasi merek produk tanah liat Kecamatan Godean yang terkenal baik kualitasnya.

Ketersediaan bahan baku, bahan tambahan, dan sumber energi merupakan hal yang berpengaruh terhadap penentuan lokasi industri dan biaya produksi (Weber 1909 dalam Smith, 1971). Adapun lokasi industri tanah liat di daeah Kecamatan Godean berdiri disebabkan dekatnya bahan baku tanah liat atau lempung yang berada di sekitar Kecamatan Godean-Seyegan. Selain itu, industri tanah liat Kecamatan Godean sendiri sudah membangun mitra usaha lain, yaitu usaha transportasi dan penambangan tanah, jasa penggilingan, dan industri kayu yang dapat juga disebut pemasok. Hal ini yang membuat berdirinya industri tanah liat di Kecamatan Godean masih dapat berlanjut dari dulu hingga sekarang.

Keberadaan industri tanah liat Kecamatan Godean yang sudah lama berdiri dan juga reputasinya yang baik membuat nama pada produknya banyak dikenal masyarakat. Pasar yang luas dengan permintaan bersifat rutin dan ditampung oleh distributor di daerah luar. Pasar yang luas ini juga dapat membuat permintaan untuk produk tanah liat semakin tinggi sehingga produksi dapat dilakukan secara rutin. Produk tanah liat produksi Kecamatan Godean juga pernah dikirim hingga mancanegara. Hal ini juga didukung oleh keberadaan pemasok 
bahan baku dan tambahan yang dekat dengan lokasi industri. Permintaan dari luar daerah merupakan hal yang sangat mempengaruhi keberlanjutan industri tanah liat karena membuktikan bahwa industri tanah liat masih memiliki masa depan yang baik dengan keadaan pasar yang baik pula.

Permintaan yang tinggi dan reputasi yang baik membuat produk tanah liat Kecamatan Godean banyak ditiru oleh pesaingnya, di mana pesaing menggunakan merek yang sama dengan produk dari Kecamatan Godean. Ironisnya, pengepul yang berlokasi di sekitar Kecamatan Godean sendiri yang menampung produk-produk dari para pesaing karena harganya lebih murah. Harga yang lebih murah ini sebanding dengan kualitas yang tidak lebih baik dibanding dengan produk asli Kecamatan Godean. Ketika konsumen tidak puas maka reputasi merek Kecamatan Godean yang rusak. Produk dari Kecamatan Godean pada umumnya memiliki warna yang lebih pucat dan bersifat lebih padat dibandingkan produk dari daerah pesaing.

Peresmian sentra industri telah membuka peluang pemerintah untuk dapat memberikan bantuan secara hukum dan legal. Salah satunya adalah dengan membantu pengrajin mempatenkan merek dari produk menjadi "Godean Super". Pemerintah juga turut serta dalam memberikan rekomendasi kepada para kontraktor yang akan melakukan suatu pembangunan di Yogyakarta. Rekomendasi pemerintah ini sangat membantu dalam menunjang permintaan akan produk di Kecamatan Godean.

Faktor-faktor lingkungan eksternal industri tanah liat yang terletak di Kecamatan Godean menunjukkan bahwa pasar dengan tingkat permintaan yang tinggi merupakan faktor utama yang dapat mendorong keberlanjutan industri. Dinamika proses produksi juga membuat industri ini memiliki pemasok tetap dan distributor yang tetap. Akan tetapi, terdapat hambatan dari pesaing, yaitu produk tiruan sehingga para pengrajin membentuk Asosiasi Pengrajin Genteng untuk mencari solusi. Solusi yang didapatkan yaitu dengan pengukuhan sentra industri dan pengukuhan merek, di mana Kecamatan Godean harus mengganti mereknya dengan merek seragam yaitu "Godean Super".

\section{Matriks IE}

Hasil perkalian antara bobot dan nilai dari faktor lingkungan internal dan juga faktor lingkungan eksternal menghasilkan skor yang akan menentukan strategi keberlanjutan industri. Berdasarkan hasil perhitungan faktor lingkungan internal memiliki nilai 2,30 dan faktor lingkungan eksternal memiliki nilai 2,42. Mengartikan bahwa posisi yang ada dalam matriks IE sesuai dengan keadaan faktor lingkungan industri tanah liat di Kecamatan Godean adalah pada sel v (Rangkuti, 2008). Sel v menunjukkan adanya pertumbuhan atau stabilisasi industri.

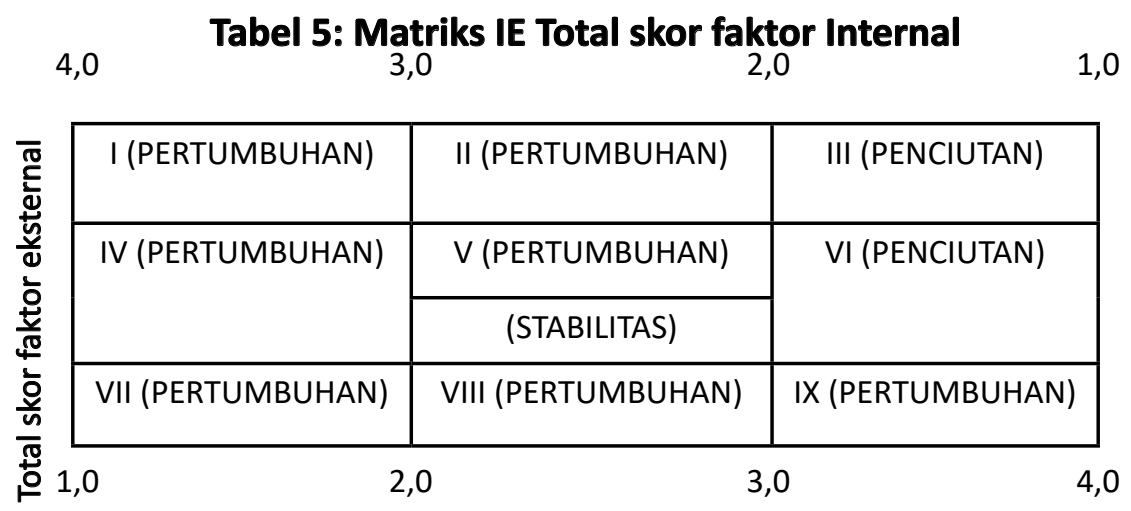

Sumber: Hasil Survey (2018) 
Berdasarkan Tabel 5 diketahui bahwa model strategi yang sebaiknya dilakukan adalah konsentrasi melalui strategi yang horizontal. Strategi ini memiliki tujuan untuk menghindari kehilangan penjualan dan keuntungan. Hal yang harus dilakukan adalah memperluas pasar, fasilitas produksi, dan pengembangan teknologi dengan cara menjaga ketersediaan bahan baku atau membuat produk yang terjamin akan terserap di pasaran (Rangkuti, 2008). Menurut David (2011), strategi secara horizontal dapat ditempuh dengan cara penggabungan atau dengan merger, akuisisi, menguasai bahan baku, serta mengkontrol pesaing.

Berdasarkan hasil, strategi yang sesuai dijalankan oleh industri tanah liat di daerah Kecamatan Godean dengan tujuan untuk mempertahankan industri adalah dengan menjaga dan menghindari kehilangan keuntungan serta fokus pada penguatan ketersediaan bahan baku dan mengontrol pesaing. Hal ini sesuai dengan keadaan industri tanah liat di Kecamatan Godean sekarang yang didasari pada permasalahan internal mengenai penerus dan bahan baku, serta pada permasalahan pesaing yang menginvansi pasar. Selain itu, menjaga dan menghindari kehilangan keuntungan dapat dilakukan dengan menguatkan merek sendiri agar lebih dikenal masyarakat.

\section{Matriks SWOT}

Berdasarkan hasil analisis yang dilakukan, ditemukan rumusan strategi keberlanjutan industry ditampilkan dalam Tabel 6. S-O strategi yang dapat diterapkan adalah dengan pengukuhan terhadap merek dan melakukan standarisasi produk. Kedua hal ini saling berhubungan. Berdasarkan penuturan oleh Informan jika keduanya terwujud maka produk dapat digunakan untuk mengisi proyek besar.

Pengukuhan mereka akan memiliki pengaruh terhadap tingkat penjualan. Mereka akan memberikan identitas tersendiri untuk produk tanah liat yang diproduksi di Kecamatan Godean. Hal ini dimana akan menguntungkan karena reputasi produk tanah liat Kecamatan Godean sudah baik dan memiliki pasar yang luas. Sementara itu, strandarisasi produk akan membuat kualitas produk terpantau.

Strategi yang telah disusun tidak dapat terwujud tanpa dukungan dari banyak pihak. Langkah awal yang dapat dilakukan para pengusaha adalah memperkuat keberadaan Asosiasi Genteng sebagai suatu organisasi pemersatu. Ketika semua pengusaha atau pengrajin sudah bersatu, maka akan mudah dalam mengambil langkah pengembangan selanjutnya.

S-T strategi dapat disusun memanfaatkan kekuatan reputasi yang sudah baik untuk mempertahankan konsumen. Cara yang juga tepat adalah dengan membuat branding produk tanah liat Kecamatan Godean. Hal ini dilakukan dengan cara memperkenalkan kekhasan produk tanah liat yang dihasilkan. Selain itu, perbaikan sistem pemasaran juga harus dilakukan. Sistem pemasaran yang dilakukan sebagian besar pengusaha industri hanya dari mulut ke mulut.

Sementara itu, pengusaha yang berusaha untuk melakukan pemasaran di internet dan brosur sangat sedikit. Padahal internet adalah media komunikasi yang mampu dalam mengatasi hambatan akses pasar. Hal ini juga dapat digunakan untuk interaksi secara langsung antara konsumen dan produsen. Selain itu, mampu memotong rantai tangan industri, sehingga keuntungan tetap terjaga dan bahkan meningkat.

W-O strategi yang tepat dilakukan dari peluang dan kelemahan yang ada yaitu meningkatkan fungsi Asosiasi Genteng yang sudah terbentuk. Fungsi organisasi tersebut dapat berperan sebagai pemasok utama bahan baku dan alat-alat industri yang dibutuhkan. Selain itu, 
Asosiasi Pengrajin Genteng juga dapat mengambil perannya sebagai koperasi simpan pinjam untuk mengatasi masalah pada kekurangan modal.

Menambah fungsi asosiasi ini terinspirasi dari sistem koperasi yang berdiri di UMKM sejenis, yaitu industri kayu di Desa Wisata Krebet, di mana Koperasi Sido Katon menyediakan alat dan juga bahan yang dibutuhkan untuk proses industri dan juga melayani simpan pinjam. Koperasi ini juga memiliki peran sebagai penyalur aspirasi pengrajin dan pintu akses ke pemerintah untuk memberi perhatian ke pada industri (Wibisono, 2017).

\section{Tabel 6: Matriks SWOT}

\begin{tabular}{|c|c|c|}
\hline & KEKUATAN(STRENGHTS) & KELEMAHAN(WAEKNESS) \\
\hline & $\begin{array}{l}\text { 1. Managemen dilakukan oleh } \\
\text { pemilikl angsung } \\
\text { 2. Inovasi mengikuti pasar } \\
\text { 3. Reputasi produk baik }\end{array}$ & $\begin{array}{l}\text { 1. Modal besar untuk memulai } \\
\text { usaha } \\
\text { 2. Tenaga kerja sulit } \\
\text { 3. Minim penurususaha } \\
\text { 4. Bahan baku langka dan mahal }\end{array}$ \\
\hline PELUANG (OPPORTUNITIES) & S-OSTRATEGI & W-OSTRATEGI \\
\hline $\begin{array}{l}\text { 1. Pasardengan permintaan tinggi } \\
\text { 2. Upaya strandarisasi dari Asosiasi } \\
\text { Pengrajin Genteng } \\
\text { 3. Pasar luas } \\
\text { 4. Dijadikan rekomendasi tempatpem- } \\
\text { belian genteng dan bata olehpemerintah } \\
\text { 5. Memiliki banyak mitra dengan } \\
\text { pemasok dan distributor }\end{array}$ & $\begin{array}{l}\text { 1. Mewujudkan pengukuhan } \\
\text { merek } \\
\text { 2. Melakukan standarisasi } \\
\text { produk }\end{array}$ & $\begin{array}{l}\text { 1. Meningkatkan fungsi Asosiasi } \\
\text { sebagaik operasi } \\
\text { 2. Meningkatkan fungsi Asosisasi } \\
\text { sebagai pengatur distribusi bahan } \\
\text { baku }\end{array}$ \\
\hline ANCAMAN(THREATS) & S-TSTRATEGI & W-TSTRATEGI \\
\hline $\begin{array}{l}\text { 1. Pesaing memalsukan merek dan ma- } \\
\text { suk ke daerah Godean }\end{array}$ & $\begin{array}{ll}\text { 1. Memanfaatkan } & \text { reputasi } \\
\text { untuk branding produk } & \\
\text { 2. Memperbaiki } & \text { sistem } \\
\text { pemasaran } & \end{array}$ & $\begin{array}{l}\text { 1. Mencari bahan subtitusi } \\
\text { 2. Mengedukasi generasi muda } \\
\text { terkait kewirausahaan } \\
\text { 3. Memperbaiki sistem manajemen } \\
\text { 4. Melakukan inovasi produk }\end{array}$ \\
\hline
\end{tabular}

Bahan baku merupakan isu penting yang sedang diupayakan untuk tetap tersedia. Jika tidak ada bahan baku maka industri tanah liat di Kecamatan Godean terancam untuk mati.

Pembangunan sedang dilakukan di beberapa titik bukit yang dijadikan sebagai bahan baku utama. Sementara itu, baik pemerintah maupun pengusaha tidak berwenang untuk melarang pembangunan karena tanah yang dijual merupakan kepemilikan pribadi. W-T strategi yang dapat disusun adalah dengan mencari bahan subtitusi atau juga bahan pengganti yang memiliki kualitas sejenis atau lebih baik.

Pencarian bahan subtitusi sedang dilakukan dan selagi mencari, Asosiasi Genteng juga sudah mengusahakan mediasi dengan pihak yang membangun di wilayah bukit bahan baku. Selain bahan baku, isu utama dalam keberlanjutan industri ini adalah minimnya penerus. 
Solusi untuk masalah ini adalah dengan mengedukasi generasi muda terkait kewirausahaan.

Generasi muda harus ditanamkan untuk menciptakan tenaga kerja dibandingkan harus menjadi tenaga kerja. Ketika generasi muda dapat dengan kreatif melanjutkan industri tanah liat, maka bukannya tidak mungkin nantinya tingkat kesejahteraan tenaga kerjanya juga akan meningkat.

Hal ini serupa dengan yang industri batik kayu di Desa Wisata Krebet, di mana sebagian besar masyarakat bekerja sebagai pengrajin termasuk generasi muda yang tinggal di sana. Selain itu, generasi muda juga dapat menciptakan inovasi yang sesuai dengan perkembangan zaman dan pasar.

\section{Diskusi}

Faktor lingkungan internal yang memiliki pengaruh terhadap keberlanjutan industri tanah liat Kecamatan Godean terdiri dari kekuatan dan kelemahan. Kekuatan yang dimiliki industri ini adalah para pengusaha melakukan managemen secara langsung, terdapat inovasi mengikuti kadaan pasar, dan reputasi produk yang baik. Sementara itu, kelemahan dari industri ini adalah modal besar, kesulitan mencari tenaga kerja, penerus usaha minim, dan bahan baku yang mulai langka. Faktor lingkungan eksternal yang juga memiliki pengaruh terhadap keberlanjutan industri tanah liat Kecamatan Godean terdiri dari peluang dan ancaman. Peluang yang dimiliki industri ini adalah permintaan yang tinggi, terbentuknya Asosiasi Pengrajin Genteng yang mengusahakan standarisasi, jangkauan pasar luas, pemerintah yang memberikan rekomendasi bagi para pengembang untuk menggunakan produk, pemasok dan juga distributor dekat dengan lokasi industri. Sementara itu, ancaman dari industri ini adalah pesaing yang masuk.

Strategi yang bertujuan mempertahankan keberlanjutan industri tanah liat di Kecamatan Godean ialah menghindari bentuk kehilangan keuntungan dan juga fokus dimana untuk mengembangkan produk. Hal ini juga dapat dicapai dengan meresmikan merek.

\section{Daftar Pustaka}

Aryanti, F. (2017). Industri Manufaktur Kecil Terpuruk, Pemerintah Harus Turun Tangan, Liputan6, Diunduh tanggal 8 Agustus 2019,https://www .liputan6.com/ bisnis/

BPS. (2017a.) Statistik Indonesia 2017. Jakarta: BPS.

BPS. (2017b). Survei industri mikro dan kecil tahunan 2017. Jakarta: BPS.

Christianto, J. (2011). Membangun daya saing daerah melalui penciptaan kompetensi inti daerah. Sleman: Dee Publish.

David, F. R. (2011). Strategic management concept and cases, 13th ed. New Jersey: Pearson Education Inc.

Dharmarani, D. W., \& Ghina, A. (2016). Identifikasi lingkungan internal dan eksternal dalam strategi pengembangan usaha pada sentra industri kaos suci Kota Bandung (studi kasus pada diaz production, hendartono outfit, dan mudji). E-Proceeding of Management, vol. 3, no. 2, hh. 1263-1271.

Ebert, R. J., \& Griffin, R. W. (2019). Business essentials, 12th ed. New York: Pearson.

Hadiati, S. (2008). Perilaku wirausaha industri keramik berskala kecil untuk meningkatkan daya saing produk di Malang. Jurnal Manajemen Dan Kewirausahaan, vol. 10, no.2, hh. 115- 
123.

LPPI, Bank Indonesia. (2015). Profil Bisnis Usaha Mikro, Kecil dan Menengah (UMKM). Jakarta.

Morissan, W, A. C., \& U, F. H. (2012). Metode penelitian survei. Jakarta: Kencana Prenada Media Group.

Prasasti, E. (2016). Studi deskriptif tentang faktor penghambat pengembangan industri kecil dan menengah di kampung binaan bordir di kelurahan kedung baruk Kecamatan Runkut Surabaya. Jurnal Kebijakan dan Manajemen Publik, vol. 4, no. 2, hh. 167-176.

Rangkuti, F. (2008). Analisis SWOT teknik membedah kasus bisnis. Jakarta: Gramedia Pustaka Utama.

Samuelson, P. A., \& Nordhaus, W. (2010). Economics, 19th ed. New York: The McGraw-Hil Company.

Sari, R. I., \& Budiani, S. R. (2018). Analisis strategi pemasaran industri tenun di Desa Wisata Gamplong Kabupaten Sleman. Majalah Geografi Indonesia, 32(1), 98-107.

Setyowati, N. W. (2015). Pengaruh lingkungan eksternal dan lingkungan internal terhadap keunggulan bersaing pada industri kecil dan menengah di Bandung Jawa Barat. Esensi Jurnal Bisnis Dan Manajemen, vol.5, no. 1, hh. 9-26.

Smith, D. M. (1971). Industrial location : an economic geographycal analysis. Canada: John Wiley \& Sons.

Tambunan, T. T. H. (2012). Peluang, tantangan dan ancaman bagi UMKM Indonesia dalam CAFTA dan ME-ASEAN 2015. Prosiding Seminar \& Konferensi Nasional Manajemen Bisnis Universitas Muria Kudus., hh. 1-14.

Wibisono. (2017). Analisis strategi pemaaran dalam meningkatkan penjualan (studi kasus di Sanggar Peni Dusun Krebet, Kelurahan Sendangsari, Kecamatan Pajangan, Kabupaten Bantul). Skripsi. Universitas Alma Ata Yogyakarta: Yogyakarta.

Yunal, V. O., \& Indriyani, R. (2013). Analisa pengaruh motivasi berwirausaha dan inovasi produk terhadap pertumbuhan usaha kerajinan gerabah di Lombok Barat. AGORA, vol. 1, no. 1. 